\title{
【シンポジウム 23】
}

\section{認知機能改善のアプローチ：運動処方の可能性を分子基盤から探る}

\author{
征 矢 英 昭 ${ }^{1}$, 七五三木 聡 $^{2}$ \\ (1筑波大学体育系, ${ }^{2}$ 大阪大学大学院医学系研究科)
}

ライフスタイルの変容は生活習慣病やストレス性疾患 の発症を誘導し, それらの罹患者数は増加の一途を辿っ ている。 その一方で, 高齢化社会の進行を反映するかた ちで認知症患者数も急増し続けており, 両疾病は, 現代 日本の社会問題を象徴する疾病としてその予防・改善は 国を挙げた課題になっている。これまで, これらの疾病 は各々の病因にもとづき, 独立したものとして扱われる ことが多かった。しかし, 近年の研究から, 両者には共 通して脳機能とりわけ海馬の司る認知機能の低下が生じ ていること，また，そのいずれに対しても運動がその予 防・改善策の一つとして有効であり, 薬物効果と同等も しくはそれ以上の効果があることが明らかになってきて いる。では，両疾病にはどのような関係があるのか，認 知機能の改善策としてどのような運動が望ましいのか, 改善効果のメカニズムは何なのか.

本シンポジウムでは，これらの疑問に答える形で 4 名 のシンポジストが講演を行った。里直行氏は, 認知症の 病因としてのアミロイドカスケード仮説に基ついて, 認 知症と糖尿病がどのように関連するのかを分子レベルで 説明した。アミロイド前駆体タンパク質 (Amyloid precursor protein, APP) の異常分解産物であるベータアミ ロイド $(\beta A)$ の蓄積・凝集・繊維状化による老人班の 形成と, これに続く神経原線維変化（異常にリン酸化し たタウ $(\tau)$ の蓄積）によって神経細胞が死滅すること で認知症が発生すると考えられているが, 前者の過程は インスリン抵抗性により立進し, 後者の過程は糖尿病に よって促進する。そのため各過程の分子カスケードの理 解が不可欠であり， $\beta \mathrm{A}+$ 危険因子 $=\tau$ リン酸化という ような単純な眓式における危険因子の同定や作用点の解 明が，発症機序に基づく患者ごとの個別のテイラー・メ イド医療確立への第一歩となることが指摘された。

島孟留氏は，神経細胞のエネルギー代謝が強く糖代謝 に依存していることから, II型糖尿病のインスリン抵抗 性によってもたらされる海馬の糖代謝異常が認知機能障 害に寄与する可能性を, II 型糖尿病ラットを用いて検討 した. II 型糖尿病ラットは海馬内グリコーゲン含有量が コントロール群より高いものの, 神経細胞の乳酸取り込 みを担う MCT2の発現量が顕著に低下していることを 見出し, エネルギー基質としての乳酸の取り込み異常が
海馬のエネルギー代謝に何らかの影響を与えている可能 性を示唆した。この MCT2 発現量が運動によって回復す ることから, 運動は海馬の代謝の正常化を通して認知機 能障害を改善できる可能性をエビデンスとして示唆した 意義は大きい.

三上俊夫氏は, 認知障害に対する運動の効果の有無と そのメカニズムについて, これまでの実験動物を用いた 研究の成果を系統的に報告した。APPを過剒に発現させ た APPトランスジェニック（アルッハイマー病モデル） マウスや $\beta A$ の脳内投与による認知機能低下マウスなど 様々な認知障害モデル動物に対して運動は認知機能の改 善を促し，またその効果は自発運動のみならず強制的運 動でも確認されている。動物実験の結果は必ずしもヒト の臨床知見に直接対応させられるものではないが, 実験 条件の統制の取れた実験動物だからこそ, 詳細にそのメ カニズムに迫ることができる。運動による $\beta$ Aのクリア ランス促進効果や海馬のニューロン新生促進効果が重要 な役割を担っているようである。

牧迫飛雄馬氏は, 実際の臨床現場における軽度認知障 害患者 (mild cognitive impairment, MCI) の認知機能回 復を目指した試みについて得られたエビデンスを報告し た。実験動物とは異なりヒトの場合は遺伝的要因の多様 性に加え，その病状も多岐にわたる。そのため，運動プ ログラムなどの有効性を確かめるには多くのサンプルが 必要となるが, 牧迫氏は, 300 名以上の MCI高齢者に対 して運動を含めた認知機能回復プログラムを処方し， ラ ンダム化比較試験として検証したところ, 運動介入群で は中強度の活動時間が有意に増加するとともに, 認知機 能, 特に記憶機能が改善していることが明らかになった。 先行研究では 1.5 3 メッツの中等度強度の運動が認知 機能改善に有効であることが指摘されており，これを支 持する結果となった，どのような運動条件が最適なのか については今後の検討を必要とすると思われるが, 高齢 化社会にともなう認知症問題の解決策として, 認知症発 症前あるいは初期段階での運動介入が非常に有効である ことがエビデンスとして明確に示されることとなった。

以上 4 名の発表から私たちは一つの強いメッセージを 得ることができた。それは，

"Physical exercise is the best medicine.". 